$\ll$ Review》

\title{
Physiological Significance of the Change in Blood Viscosity of Broiler Chickens under High Ambient Temperature
}

\author{
Weitong ZHou \\ Poultry Research Farm, Hosoya \& Co., Ltd. \\ 590-2 Tanno, Ogasa-Cho, Shizuoka-Ken, 437-1501, Japan
}

\section{Introduction}

Broiler chickens are characterized by their fast growth and great feed intake. By 56-day-old, body weight of broiler increases to $3.9 \mathrm{~kg}$ for male, $3.1 \mathrm{~kg}$ for female (Ross BREeders LtD., 1999). Feed intake in broiler is twice or more as great as in growing layer, at the same body weight. Unfortunately, fast grow th is not only accompanied by a number of problems - namely, excess body fat deposition, ascite syndrome, a high incidence of metabolic diseases and tibial dyschondroplasia, as reviewed by LEESON and Summers (1988), but also leads to broiler production being easily affected by heat stress. Many reports have exhibited the effects of high ambient temperature on performance of broiler chickens (ReEce and LotT, 1983 ; Meltzer, 1986 ; Howlider and Rose, 1989 ; Smith and TeEter, 1993 ; Yahav et al., 1996).

Growth rate and feed intake decrease markedly with the rise in ambient temperature above $21^{\circ} \mathrm{C}$ (Howlider and Rose, 1987). According to the results obtained by DoNKOH (1989), in male commercial broiler chickens from 3 to 7 weeks of age, the growth rate and feed intake decrease by about $2 \%$ and $1 \%$, respectively, with per $1^{\circ} \mathrm{C}$ rise in ambient temperature from 20 to $35^{\circ} \mathrm{C}$. The growth reduction attributable to high temperature is the largest in the birds with the fastest growth rate at normal temperature (CAHANER and LEENSTRA, 1992).

In the field, there is a higher mortality in broilers due to heat stress and males are more affected than females. Economic losses attributable to heat prostration are especially large because they usually occur after $35 \mathrm{~d}$ of age (XIN et al., 1994 ; ZHou, 1996 b). Heat-induced death of broilers occurs when their normal thermoregulation (heat balance) is disrupted (ZHOU et al., 1997 b).

This review describes some thermoregulatory physiological responses and the significance of the decreased blood viscosity in broiler chickens under high ambient temperature.

Received July 6, 1999 Accepted April 17, 2000

高温下に抢けるブロイラーの血液粘度変化の生理的意義

周 維統, (株) ホソヤ, 神奈川県綾瀬市深谷 412, 252-1103

Key words : Blood viscosity, broiler chickens, high ambient temperature, thermoregulatory response

キーワード : 血液粘度, ブロイラー, 高環境温度, 体温調節性生理反応 


\section{General aspect of thermoregulatory responses to ambient temperature}

Thermoregulatory responses of broiler chickens to ambient temperature, especially high temperature, differ from laying hens. In broilers near marketable body size, both heat production and heart rate which is related to heat production (Y амамото, 1989) decrease with the rise in ambient temperature below $28^{\circ} \mathrm{C}$, while increase above $28^{\circ} \mathrm{C}$ (Kettlewell and Moran, 1992 ; Zhou, $1996 \mathrm{a}$; Zhou and Yamamoto, 1997). Abdominal temperature fails to increase with the rise in ambient temperature below $22^{\circ} \mathrm{C}$, but increased above $22^{\circ} \mathrm{C}$. Respiration rate begins to increase around $28^{\circ} \mathrm{C}$ (Murphy and Preston, 1988 ; Zhou and Yamamoto, 1997).

In laying hens, it has been found that heat production and heart rate decrease with the rise in ambient temperature until $36^{\circ} \mathrm{C}$ (VAN KAMPEN et al., 1978 ; Li et al., 1992). Heart rate begins to increase from $36^{\circ} \mathrm{C}$ (Yамамото et al., $1975 \mathrm{a}$; Katsuda and TABA, 1985). Abdominal temperature varies little with ambient temperature below $28^{\circ} \mathrm{C}$ and increase with the rise in ambient temperature above $28^{\circ} \mathrm{C}$ (Li et al., 1992). Y Yмamoto et al. (1975 a) and KATSUDA and TABA (1985) reported that the obvious increase in rectal temperature took place after environmental temperature exceeded $35^{\circ} \mathrm{C}$. Panting begins to occur intermittently around $30^{\circ} \mathrm{C}$ (Y Aмамото et al., $1975 \mathrm{a}$, b ; Shishido, 1977 ; UWAGAWA et al., 1980 ; KATSUdA and TABA, 1985 ; Li et al., 1989).

These results show that broiler near marketable body size has a narrower zone in optimum ambient temperature and is more susceptible to the change of ambient temperature than laying hen. However, the thermoregulatory responses to ambient temperature are related to age of broilers. In the younger birds with incomplete feather growth, heat production decreases with the rise in ambient temperature until $34^{\circ} \mathrm{C}$, and the obvious increases in rectal temperature and respiration rate occur around $35^{\circ} \mathrm{C}$ (Misson, 1982 ; Hayashi, 1998). This difference arises because body plus plumage thermal resistance of broiler is constant at $0.09 \mathrm{~m}^{2} \mathrm{~K} / \mathrm{W}$ up to $30 \mathrm{~d}$ and increases linearly to $0.40 \mathrm{~m}^{2} \mathrm{~K} / \mathrm{W}$ at $54 \mathrm{~d}$ (Wathes and CLARK, 1981).

Fast growth and great feed intake of broiler chickens lead to greater heat production. Factors influencing heat production have been summarized by HiLlman et al. (1985) and Yамамото $(1987,1992)$ in animals. In those papers, feed intake and physical activities have been recognized as main factors to increase heat production. Heat production increases with increase in feed intake (Li et al., 1992 ; WiERnusz and TeEter, $1993 ;$ Z HOU and Yамамото, 1997). The heat production associated with feed intake accounts for about $16 \%$ of metabolic energy intake in laying hens under $22^{\circ} \mathrm{C}$ (Li et al., $1991 \mathrm{~b}$ ). VAN KAMPEN (1976) reported that heat production increased by $25 \%$ during standing with spontaneous activity compared with that during sitting in laying hens. Li et al. (1991 a) found that average heat production during the dark period was $33 \%$ lower than that during the light period, and about $76 \%$ of the light-dark difference in heat production was associated with activity. Under thermoneutral temperature, activities of broilers are less, compared to those of laying hens (Murphy and Preston, 1988 ; PRESTON and Murphy, 1989). During a day, the time of $72.6-79.7 \%$ is taken to lie in broilers, while only $41.3-49.5 \%$ in laying hens (SAvORY, 1975). However, under high temperature, lying time decreases in broilers, accompanied with an increase in 
standing-lying frequency (ZHOU et al., 1997 a), while increases in laying hens (ZHOU et al., $1996 \mathrm{a})$. This may be one of the reasons why heat production of broilers increases under high ambient temperature (INoue et al., 1995 ; Zhou and Y AмAмото, 1997 ; Zhou et al., $1997 \mathrm{a}, \mathrm{c})$.

The elevation of heat production increases the thermoregulatory load of the birds under warm environmental conditions and leads to abrupt thermoregulatory physiological responses. The heat produced is firstly stored in body to increase body temperature, then the responses in heat loss is followed (SHISHIDO, 1977 ; ZHOU et al., 1996 b) ; that is, the rise in body temperature preceds the change in heat loss. The effect of heat production on abdominal temperature, shank skin temperature, respiration rate etc. is influenced by environmental temperature. ZHоU and Y Амамото (1997) reported that, with increasing heat production, the greatest increase in shank skin temperature was around $28^{\circ} \mathrm{C}$, in respiration rate around $32^{\circ} \mathrm{C}$, and in abdominal temperature above $36^{\circ} \mathrm{C}$. Under warm condition, author (Zно and Y Амамото, 1997) obtained that an increase of $1 \mathrm{~kJ} / \mathrm{h}$ per metabolic body size in heat production led to a rise of about $0.07^{\circ} \mathrm{C}$ in abdominal temperature, while a rise of $1^{\circ} \mathrm{C}$ in ambient temperature about $0.2^{\circ} \mathrm{C}$. Although the effect of the increased heat production $\left(1 \mathrm{~kJ} / \mathrm{kgW}^{0.75} \mathrm{~h}\right)$ on thermoregulatory responses is not greater than that of environmental temperature $\left(1^{\circ} \mathrm{C}\right)$, the increase in heat production enhances obviously the effect of environmental temperature on thermoregulatory responses. Therefore, arranging feeding management and reducing activities to restrict the increase in heat production may alleviate the effect of high ambient temperature.

In thermoregulation, heat production of homoiothermic animals equals heat loss plus a change of heat storage owing to a change of body temperature. Heat loss is classified into sensible (convective, conductive and radiative) and latent (evaporative) heat loss. Under lower (cold) ambient temperature, heat production increases and blood vessels in naked skin and extremities contract to keep deep body temperature constant, while heat production decreases and evaporative heat loss increases under high (hot) ambient temperature because sensible heat loss is limited. In birds, respiratory evaporative heat loss is a main mode because there is no sweat gland.

However, it is not easy to maintain a constant deep body temperature ; that is, deep body temperature always changes within a range with environmental conditions. The change of the deep body temperature has an important role in maintaining heat balance under a given condition. This leads to a series of thermoregulatory responses. It has been shown that, in chickens, a change in body temperature occurs earlier than those in respiration rate and shank skin temperature (SHISHIDO, 1977 ; ZHOU et al., 1996 b). As body temperature increases, expired minute volume is augmented by large increases in respiratory frequency, although tidal volume is diminished (BARNAS and RAUTENBERG, 1987). With further increases in body temperature, tidal volume begins to increase towards normal and respiratory frequency decreases.

It has been found that heat production and heart rate increase intensely when deep body temperature exceeds $42.5^{\circ} \mathrm{C}$ (KATSUDA and TABA, 1985 ; ZHOU et al., $1997 \mathrm{~b}, \mathrm{c}$ ). Respiration rate increases markedly with deep body temperature above $41.5^{\circ} \mathrm{C}$, reaches 
a maximum when deep body temperature is around $42.5^{\circ} \mathrm{C}$. The naked skin temperature changes rapidly with deep body temperature below $41.5^{\circ} \mathrm{C}$, while the change is little above $41.5^{\circ} \mathrm{C}$ (ZHou et al., $1996 \mathrm{~b}, 1997 \mathrm{~b} ; Z_{\text {Hou }}$ and Yамамото, 1997). Thermoregulatory ability is gradually lost when deep body temperature exceeds $42.5^{\circ} \mathrm{C}$ and heat balance is broken. These results indicate that the change of deep body temperature has an important role in thermoregulatory responses of broilers.

As a way to cope with heat, heat acclimation is being utilized and studied deeply in broiler industry in tropical countries. After broilers are subjected to several hours heating episodes daily for several days, the mortality of the birds attributable to heat prostration decreases (DeAton et al., 1986 ; Davis et al., 1991). Zhou et al. (1996 a) found that the effect of acclimation to heat was recognized when birds were exposed to high ambient temperature for 8 hours per day only for 3 days. It has been reported that the broiler chickens experienced a high temperature at an early age have a higher weight gain and lower mortality due to heat stress than the inexperienced ones (ARJONA et al., 1988, 1990 ; Yahav and Plavnik, 1999). Heat-acclimated chickens have a lower heat production, heart rate, body temperature, standing-lying frequency, higher panting rates and standing time when subsequently subjected to exposure to high ambient temperature than unacclimated birds (Sykes and FATAFTAH, 1986; MAy et al., 1987; Ueno and Otani, 1987 ; Teeter et al., 1992 ; Zhou et al., $1996 \mathrm{a}, 1997 \mathrm{a}$ ), indicating that heat acclimation depresses heat production and increases heat loss.

\section{Change in blood viscosity under high ambient temperature}

Blood is a medium for transporting nutrients, metabolic waste products and gases around the body. It also plays an important role in the transportation of heat. Change of blood viscosity may effectively alter peripheral resistance and thus perfusion and circulatory distribution, including the blood supply to heat exchange surfaces. Blood is a non-Newtonian fluid. Its viscosity depends on the cell concentration, the deformational properties of the cells, cell aggregation and plasma viscosity (Chien, 1982 ; Smith and Kampine, 1990).

Both whole and plasma blood viscosity tend to increase with age in broilers (Kranen et al., 1996 ; RoBertson and Maxwell, 1996). Whole blood viscosity is greater in ascitic broilers than in normal birds, while plasma viscosity was lower (MAXwell et $a l ., 1992$; FEDDE and Wideman, 1996). The raised viscosity in the ascitic birds is caused by polycythemia and contributed to pulmonary hypertension.

Hocking et al. (1994) found that the blood viscosity in fat broiler breeders, which had a high mortality and body temperature, was twice or more as great as in lean breeders. Blood viscosity decreases significantly when broiler chickens are exposed to a high ambient temperature (ZHou et al., $1997 \mathrm{a}, 1998 \mathrm{a}$, b). Similar response is also found in red blood cells or haematocrit. Such heat-induced decrease in blood viscosity can be observed after $1 \mathrm{~h}$ of exposure and occurs at or above $25^{\circ} \mathrm{C}$ of ambient temperature (ZHOU et al., 1999 a). This decrease also takes place even though broilers are in dehydrating condition (ZHOU et al., 1999 b). However, the decrease in blood viscosity attributable to heat exposure is not a linear relation to ambient temperature. Such decrease is not enhanced by the further rise in ambient temperature above $25^{\circ} \mathrm{C}$ and 
there is no difference in blood viscosity between ambient temperatures below $20^{\circ} \mathrm{C}$ (ZHou et al., $1999 \mathrm{a}, \mathrm{c}$ ).

The heat-induced decrease in whole blood viscosity is caused by an elevation in plasma volume. Plasma volume increases when chicken is exposed to high temperature (Whittow et al., 1964 ; Arad et al., 1989 ; Yahav et al., 1997 ; Zhou and Yamamoto, 1998 ; ZHou et al., 1999 c). The increase in plasma water may come from two sources : extravascular spaces and the alimentary tract. Extracellular fluid volume is reduced significantly in the heat-exposed birds (ZноU and Yамамото, 1998 ; Z HоU et al., 1999 c). It is well known that water intake increases in heat-exposed birds. The increased water intake induces an elevated urine production and the water does not simply pass through the alimentary tract (OKumura et al., 1977 ; V AN Kampen, 1981), indicating the consumed water enters into the blood circulation. Thus blood viscosity and plasma osmolality are decreased by the increased water intake (ZHоU et al., $1999 \mathrm{~d}$ ).

In addition, there is a diurnal variation in whole blood viscosity of broilers, which is greater during the dark than during the light period, accompanied by similar variation in red blood cells and haematocrit (Zhou et al., 1998 a). OKaWARA et al. (1985) reported that haematocrit was higher at night than during day time in Japanese quails. However, haematocrit of humans showed lower value at night (TAMURA, 1957 a). These diurnal variations in blood viscosity and haematocrit may be a result of water redistribution in the body caused by sleep or lower metabolic rate. In humans, TAMURA (1957 b) found that blood water content increased and haematocrit decreased during sleep even though it was the daytime.

It has been reported that blood viscosity is significantly lower in chronically restricted-fed broiler breeders than in ad libitum-fed birds (Hocking et al. 1994). ZHou et al. (1998 a) found that blood viscosity, compared to ad libitum-fed broilers, was markedly lower in the birds deprived of feed and water for $15 \mathrm{~h}$, and tended to be higher after deprivation of feed and water for $21 \mathrm{~h}$. Blood viscosity is increased by feed intake and decreased after feeding, but these change is related to the water/feed ratio (ZHOu et al., 1999 d).

It is well known that heat exposure induces an increase in blood flow rate of heat exchange organ and surfaces, such as comb and foot (HILlman et al., 1985 ; ARAD et al., 1993), resulting in an increase in sensible heat loss. VAN KAMPEN (1971) found that sensible heat loss from comb and wattles represented $34 \%$ of total sensible heat loss at $35^{\circ} \mathrm{C}$. Up to now, it is recognized that such increase in blood flow rate is only attributed to vasodilation. WhiтTow et al. (1964) mentioned that the decrease in total peripheral resistance to blood flow was attributed partly to the increased blood flow through the extremities. Hocking et al. $(1992,1994)$ and Macleod and Hocking (1993) pointed out that the higher mortality in ad libitum-fed fat line birds may be attributed partly to the greater blood vicosity. Besides these, there is no further evidence appraising the role of whole blood viscosity in thermoregulation. As illustrated above, in recent years, author revealed that an elevation in blood flow rate of heat exchange organ and surfaces was also contributed by a fall in blood viscosity under high ambient temperature. Blood flow is related to its viscosity. The following 
equation shows the relationship between blood flow rate and factors influencing it (SMith and KAMPINE, 1990).

$$
Q=\frac{\Delta P r^{4} \pi}{\eta L 8}
$$

Where $Q=$ blood flow rate, $\Delta P=$ the difference between arterial and venous blood pressure of organ or tissues, $r=$ the radius of blood vessel, $\eta=$ blood viscosity, $L=$ the length of blood vessel.

Peripheral vessel vasodilation leads to a decrease in blood pressure. During heat exposure, arterial blood pressure falls significantly and is kept at lower level (WHITTOW et al., 1964 ; DARRE and HARRISON, 1987), resulting in a smaller $\triangle P$ because venous blood pressure is very low and stable (SMith and Kampine, 1990). From the equation illustrated above, it is known that blood flow rate of heat exchange organ and surface is reduced when $\Delta P$ decreases. This decrease phenomenon may be compensated by the increases in blood volume and cardiac output and reduction of blood viscosity. WhitTow et al. (1964) and DARRE and HARRISON (1987) observed that cardiac output and stroke volume increased significantly when chickens were exposed acutely to high temperature. It has been found that blood volume expands when the birds are exposed to high ambient temperature, accompanied by a decreased blood viscosity (Zhоu and Yамамото, 1998 ; Zhou et al., 1999 c). It is noticed that a lower comb surface temperature and a lower rise in back skin temperature with the rise of rectal temperature have a contribution of a higher blood viscosity in dehydrated broilers (ZHOU et al., $1999 \mathrm{~b})$. Conversely, decrease of blood viscosity is advantageous to the increase of blood flow rate in heat exchange organs, increasing their heat exchange efficiency.

However, heat-induced decrease in blood viscosity occurs only above $25^{\circ} \mathrm{C}$ of ambient temperature or above $41.5^{\circ} \mathrm{C}$ of deep body temperature (ZHou et al., 1999 a). It is observed that the naked skin temperature of chickens changes easily with the change in deep body temperature when deep body temperature is below $41.5^{\circ} \mathrm{C}$, while peripheral vessels dilates completely and skin temperature rise passively above $41.5^{\circ} \mathrm{C}$ (ZHOU et al., 1996 b, 1997 b). These phenomena may indicate that the decrease in blood viscosity is related to peripheral vasodilation.

As summrized in Fig. 1, high temperature exposure induces a series of neurohormonal responses, resulting in cutaneous vasodilation (especially in extremities), increases in respiratory frequency and water intake and reduction in feed intake. Cutaneous vasodilation leads to an increase in cutaneous blood flow, and simultaneously to a blood volume expansion, resulting in a fall in blood viscosity. Both an increase in water intake and a decrease in feed intake also induce a decrease in blood viscosity. The decreased blood viscosity improves increase in blood flow rate to heat exchange organs (lung, respiratory tract) and skin surface. The increase in cutaneous blood flow makes both cutaneous temperature and cutaneous heat conductance increase (OHARA, 1981), resulting in increase in sensible heat loss, and the increased blood flow in respiratory organs makes heat exchange efficiency of respiratory organs increase. However, the decrease in blood viscosity occurs only when the environment changes from thermoneutral to high ambient temperature. This is advantageous to 


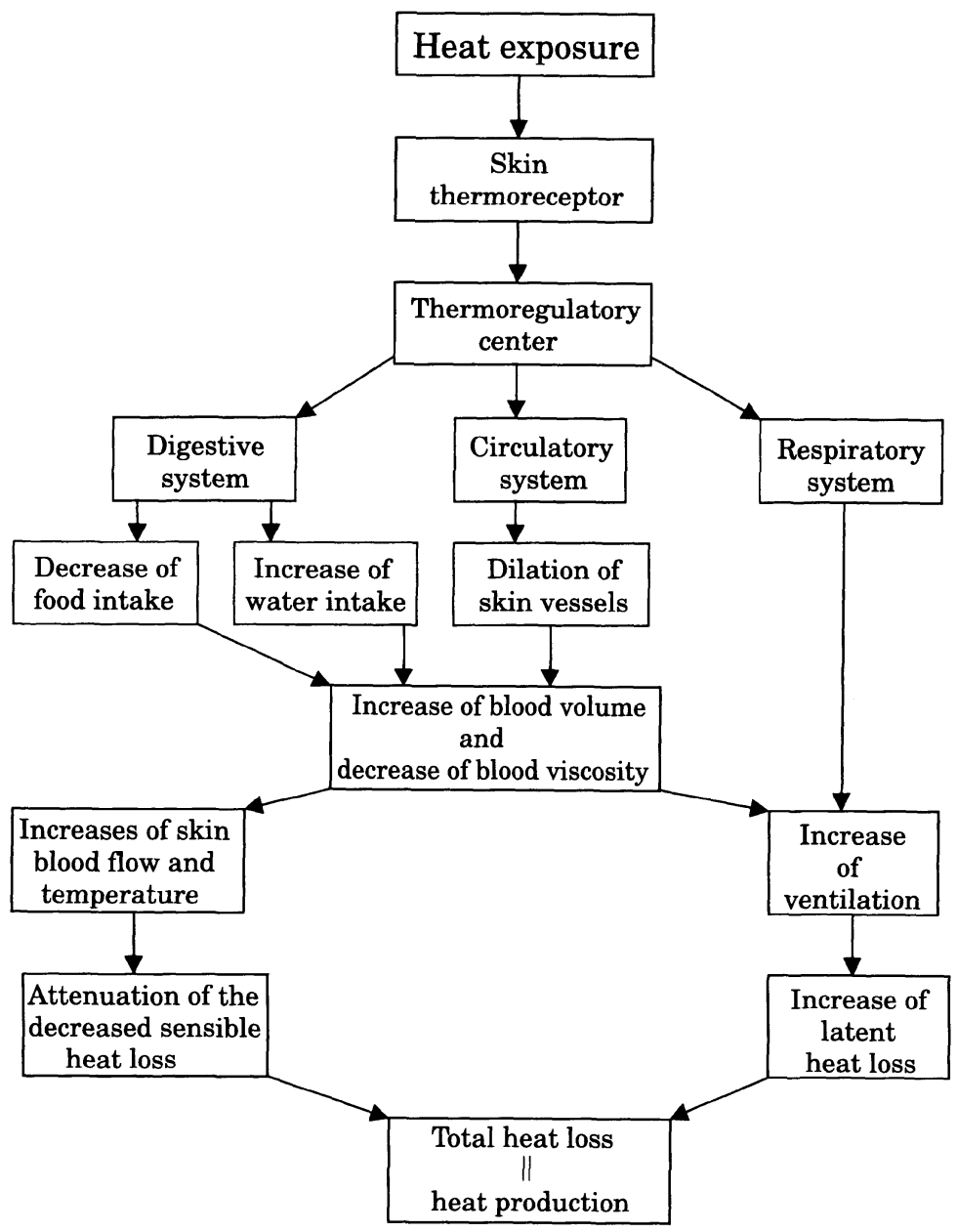

Fig. 1. A schematic in thermoregulation of broiler under high ambient temperature.

increase heat loss.

\section{Acknowledgements}

I feel very honored to be given this chance by the editorial board of Japanese Poultry Science to review this paper which was summarized according to the main contents of my research project (Studies on thermoregulation of broilers under high ambient temperature) awarded (The Encouragement Award, 1998) by Japan Poultry Science Association. The research works were carried out in Hiroshima University, Japan. Great indebtedness is given to my supervisor, Prof. S. Y АмАмото, for his kind guidance, and to Profs. T. ITO and M. FuJITA for their support and encouragement. Thank is also given to Dr. H. YANG, University of Minnesota, USA, for his valuable comments and corrections on this manuscript. 


\section{References}

Arad, Z., Horowitz, M., Eylath, U. and Marder, J. (1989) Osmoregulation and body fluid compartmentalization in dehydrated heat-exposed pigeons. American Journal of Physiology, $257: \mathrm{R}$ 377-R382.

Arad, Z., El-SAyed, M.S. and BrankEnBury, J.H. (1993) Effect of acute heat exposure on blood flow and its distribution in the unrestrained laying fowl (Gallus domesticus). British Poultry Science, $34: 559-568$.

ArJona, A.A., Denbow, D.M. and Weaver, W.D. (1988) Effect of heat stress early in life on mortality of broilers exposed to high environmental temperatures just prior to marketing. Poultry Science, $67: 226-231$.

ArJona, A.A., Denbow, D.M. and Weaver, W.D. (1990) Neonatally-induced thermotolerance : physiological responses. Comparative Biochemistry and Physiology, 95A : 393-399.

Barnas, G.M. and Rautenberg, W. (1987) Temperature control. In 'Bird Respiration (Seller, T.J. ed.)' Vol. 1, pp. 131-153. CRC Press, Boca Raton, Florida.

CAhaner, A. and LeEnstra, F. (1992) Effects of high temperature on growth and efficiency of male and female broilers from lines selected for high weight gain, favorable feed conversion, and high or low fat content. Poultry Science, $71: 1237-1250$.

ChIEN, S. (1982) Hemorheology in clinical medicine (a review). Clinical Hemorheology, 2 : 137-142.

DARRE, M.J. and HaRRISON, P.C. (1987) Heart rate, blood pressure, cardiac output, and total peripheral resistance of single comb White Leghorn hens during an acute exposure to $35^{\circ} \mathrm{C}$ ambient temperature. Poultry Science, $66: 541-547$.

Davis, G.S., Edens, F.W. and ParkhuRst, C.R. (1991) Computer-aided heat acclimation in broiler cockerels. Poultry Science, $70: 302-306$.

DeAton, J.W., ReEce, F.N., BRANTon, S.L. and MAy, J.D (1986) High environmental temperature and broiler livability. Poultry Science, $65:$ 1268-1269.

DonkoH, A. (1989) Ambient temperature : a factor affecting performance and physiological response of broiler chickens. International Journal of Biometeorology, 33: 259-265.

FEDDE, M.R. and WIDEMAN, JR.R.F. (1996) Blood viscosity in broilers: Influence on pulmonary hypertension syndrome. Poultry Science, $75: 1261-1267$.

HAYASHI, K. (1998) Nutritional and physiological responses of broilers against heat stress. Proceedings of the 6th Asian Pacific Poultry Congress, pp. 141-146. Nagoya, Japan.

Hillman, P.E., ScotT, N.R. and van Tienhoven, A. (1985) Physiological responses and adaptations to hot and cold environments. In : 'Stress Physiology in Livestock (Yousef, M.K. ed.)' Vol. 3, pp. 1-71. CRC Press, Boca Raton, Florida.

Hocking, P.M., McCoRMack, H. and Whitehead, C.C. (1992) Plasma oestrogen concentrations and reproductive characteristics of broiler chickens after ten generation of selection at seven weeks of age for high or low plasma very low density lipoprotein concentration. British Poultry Science, 33 : 1043-1056.

Hocking, P.M., Maxwell, M.H. and Mitchell, M.A. (1994) Haematology and blood composition at two ambient temperature in genetically fat and lean adult broiler breeder females fed ad libitum or restricted throughout life. British Poultry Science, 35 : 799-807.

Howlider, M.A.R. and Rose, S.P. (1987) Temperature and the growth of broilers. World's Poultry Science Journal, $43: 228-237$.

Howlider, M.A.R. and Rose, S.P. (1989) Rearing temperature and the meat yield of broilers. British Poultry Science, $30: 61-67$.

Inoue, Y., Zhou, W.T. and Yamamoto, S. (1995) Effects of short time heat exposure on thermoregulating physiological responses and heat acclimation in broilers. Japanese Poultry Science, $32:$ : 289-295.

KATSUDA, S. and TABA, N. (1985) Changes in rectal temperature, respiration rate and electrocardiogram to high environmental temperature in constrained hens. The Japanese Journal of Zootechnical Science, 56 : 925-930.

Kranen, R.W., Veerkamp, C.H, Lambooy, E., van Kuppevelt, T.H. and Veerkamp, J.H. (1996) Hemorrhage in muscles of broiler chickens: The relationships among blood variables at 
various rearing temperature regimens. Poultry Science, 75 : 570-576.

Kettlewell, P.J. and Moran, P. (1992) A study of heat production and heat loss in crated broiler chickens : a mathematical model for a single bird. British Poultry Science, 33 : 239-252.

LeEson, S. and Summers, J.D. (1988) Some nutritional implication of leg problems with poultry. British Veterinary Journal, $144: 81-92$.

Li, Y., Iто, T. and Yамамото, S. (1989) Heat production and evaporative heat loss of laying hens under high environmental temperature. Japanese Journal of Livestock Management, 25 : 5558.

Li, Y., Ito, T. and Yamamoto, S. (1991 a) Diurnal variation in heat production related to some physical activities in laying hens. British Poultry Science, 32 : 821-827.

Li, Y., Ito, T. and Yамамото, S. (1991 b) Use of limited daily access to food in measuring the heat production associated with food intake in laying hens. British Poultry Science, 32 : 829-839.

Li, Y., Ito, T., Nishibori, M. and Yamamoto, S. (1992) Effects of environmental temperature on heat production associated with food intake and on abdominal temperature in laying hens. British Poultry Science, $33: 113-122$.

Macleod, M.G. and Hocking, P.M. (1993) Thermoregulation at high ambient temperature in genetically fat and lean broiler hens fed ad libitum or on a controlled-feeding regime. British Poultry Science, $34: 589-596$.

Maxwell, M.H., Robertson, G.W. and McCorquodale, C.C. (1992) Whole blood and plasma viscosity values in normal and ascitic broiler chickens. British Poultry Science, 33 : 871-877.

May, J.D., DeAton, J.W. and BRAnton, S.L. (1987) Body temperature of acclimated broilers during exposure to high temperature. Poultry Science, $66: 378-380$.

Meltzer, A. (1986) Efficiency of effect of high ambient temperatures on food utilisation in male broilers. British Poultry Science, 27 : 349-351.

Misson, B.H. (1982) The thermoregulatory responses of fed and starved 1-week-old chickens (Gallus domesticus). Journal of Thermal Biology, 7 : 189-192.

Murphy, L.B. and Preston, A.P. (1988) Time-budgeting in meat chickens grown commercially. British Poultry Science, $29: 571-580$.

OHARA, K. (1981) Skin temperature. In 'Thermal Physiology (NAKAYAMA, T. ed.)' pp. 10-13. Rikogaku Press, Tokyo.

Okawara, Y., Karakida, T., Yamaguchi, K. and Kobayashi, H. (1985) Diurnal rhythm of water intake and plasma angiotensin II in the Japanese quail (Coturnix coturnix japonica). General and Comparative Endocrinology, $58: 89-92$.

Okumura, J., TASAKI, I. and SAITO, K. (1977) Relation between ambient temperature and relative humidity and wet droppings in chickens. Japanese Poultry Science, 14 : 217-222.

Preston, A.P. and Murphy, L.B. (1989) Movement of broiler chickens reared in commercial condition. British Poultry Science, $30: 519-532$.

ReEce, F.N. and LotT, B.D. (1983) The effects of temperature and age on body weight and feed efficiency of broiler chickens. Poultry Science, 62 : 1906-1908.

Robertson, G.W. and Maxwell, M.H. (1996) Plasma viscosity value and the relationship with age and sex in normal commercial broiler and layer strains of chickens. British Poultry Science, $37: 309-316$.

Ross Breeder Ltd. (1999) Producing Quality Broiler Meat - The Management Manual of Chunkey Broiler (in Japanese). Chunkey Association Press, Japan.

SAVORY, C.J. (1975) A growth study of broiler and layer chicks reared in single-strain and mixed-strain groups. British Poultry Science, 16 : 315-318.

Shishido, H. (1977) On the changes of respiratory rate and its mean process during panting of chickens. Japanese Poultry Science, 14 : 153-161.

Smith, J.J. and Kampine, J.P. (1990) Circulatory Physiology - the essentials (3rd edition), pp. 16-30. Williams and Wilkins, Baltimore, USA.

Smith, M.O. and TeETER, R.G. (1993) Effects of feed intake and environmental temperature on chick growth and development. Journal of Agricultural Science, Cambridge, 121 : 421-425.

Sykes, A.H. and Fataftah, A.R.A. (1986) Acclimatisation of the fowl to intermittent acute heat stress. British Poultry Science, 27 : 289-300. 
TAmuRA, M. (1957 a) Studies on sleep and narcosis from the view-point of blood water picture. I. Diurnal change of blood water picture. Shikoku Acta Medica, 10 : 423-425.

TAmuRA, M. (1957 b) Studies on sleep and narcosis from the view-point of blood water picture. II. Change of blood water picture in the sleep. Shikoku Acta Medica, 10 : 426-429.

TeETer, R.G., Smith, M.O. and Wiernusz, C.J. (1992) Broiler acclimation to heat distress and feed intake effects on body temperature in birds exposed to thermoneutral and high temperature. Poultry Science, 71 : 1101-1104.

Ueno, T. and OtANI, F. (1987) Effects of acclimatization to heat on body temperature, respiration rate, and blood acid-base values in two strains of White Leghorn. Japanese Poultry Science, $24: 304-312$.

Uwagawa, S., Ito, T. and Yamamoto, S. (1980) Influence of air velocity and ambient temperature on physiological responses of laying hens. The Japanese Journal of Zootechnical Science, 51 : 471-477.

VAN KAMPEN, M. (1971) Some aspects of thermoregulation in the White Leghorn fowl. International Journal of Biometeorology, $15: 244-246$.

VAN KAMPEN, M. (1976) Activity and energy expenditure in laying hens. 3. The energy cost of eating and posture. Journal of Agricultural Science, Cambridge, 87 : 85-88.

VAN KAMPEN, M. (1981) Water balance of colostomised and non-colostomised hens at different ambient temperatures. British Poultry Science, $22: 17-23$.

VAN Kampen, M., Mitchell, B.W. and Siegel, H.S. (1978) Influence of sudden temperature changes on oxygen consumption and heart rate in chickens in light and dark environments. Journal of Agricultural Science, Cambridge, $90: 605-609$.

WATHES, C.M. and ClARK, J.A. (1981) Sensible heat transfer from the fowl : Radiative and convective heat losses from a flock of broiler chickens. British Poultry Science, 22 : 185-196.

Whittow, G.C., Sturkie, P.D. and Stein, G. JR. (1964) Cardiovascular changes associated with thermal polynea in the chicken. American Journal of Physiology, 207 : 1349-1353.

Wiernusz, C.J. and TEeter, R.G. (1993) Feeding effects on broiler thermobalance during thermoneutral and high ambient temperature exposure. Poultry Science, 72 : 1917-1924.

Xin, H., BerRy, I.L., BARTON, T.L. and TABLER, G.T. (1994) Feed and water consumption, growth, and mortality of male broilers. Poultry Science, $73: 610-616$.

Yahav, S., Straschnow, A., Plavnik, I. and Hurwitz, S. (1996) Effects of diurnally cycling versus constant temperatures on chicken growth and food intake. British Poultry Science, 37 : 43-54.

Yahav, S., Straschnow, A., Plavnik, I. and Hurwitz, S. (1997) Blood system response of chickens to changes in environmental temperature. Poultry Science, 76 :627-633.

YaHAV, S. and PlavNiK, I. (1999) Effect of early-age thermal conditioning and food restriction on performance and thermotolerance of male broiler chickens. British Poultry Science, $40: 120-$ 126.

Yamamoto, S., Ito, T. and MimuRA, K. (1975 a) The physiological responses of the chicken to the high environmental temperature. The Japanese Journal of Zootechnical Science, $46: 19-23$.

Y амамото, S., Fuji, M. and Mimura, K. (1975 b) Studies on correlation between respiration rate and evaporative loss of the laying hens. The Journal of Zootechnical Science, 46 : 167-171.

Yамамото, S. (1987) Current knowledge of the management of thermal factors for poultry production (a review). Japanese Poultry Science, 24 : 209-219.

Yамамото, S. (1989) Estimation of heat production from heart rate measurement of free living farm animals. Japan Agricultural Research Quarterly, 23 : 134-143.

ҮАмАмото, S. (1992) Management of thermal environment for animal production (a review). Animal Science and Technology, 63 : 743-755.

ZHOU, W.T. (1996 a) Effects of environmental temperature on thermoregulatory responses in broiler chickens. Proceedings of the 20th World's Poultry Congress, Vol. 4, p. 121, World's Poultry Science Association (India Branch, New Delhi).

ZHоU, W.T. (1996 b) The characteristics in behavior and thermoregulatory responses of broiler chickens and heat countermeasure (a review, in Japanese). Animal Husbandry, 50 : 591-598.

Zhou, W.T., Fujita, M., Ito, T. and Yamamoto, S. (1996a) Effects of intermittent short term acclimation to $32^{\circ} \mathrm{C}$ on some thermoregulatory responses and standing behavior of laying 
hens exposed to acutely to $36^{\circ} \mathrm{C}$. Japanese Poultry Science, $33: 221-229$.

ZHOU, W.T., WANG, J.Y. and YAmamoTo, S. (1996 b) Effects of heat production attributable to forced walking on thermoregulatory physiological responses of chickens in a warm environment. British Poultry Science, $37: 829-840$.

Zhou, W.T., Fujita, M., Ito, T. and Yamamoto, S. (1997a) Effects of early heat exposure on thermoregulatory responses and blood viscosity of broilers prior to marketing. British Poultry Science, $38:$ 301-306.

Zhou, W.T., Fujita, M., Iтo, T. and Yамамото, S. (1997 b) The relationships between abdominal temperature and some thermoregulatory responses in male broiler chickens. AsianAustralasian Journal of Animal Science, 10 : 652-656.

Zhou, W.T., Inoue, Y., Iто, T. and Y амамото, S. (1997 c) Effects of feed intake prior to heat exposure on thermoregulatory physiological responses of broilers. Japanese Journal of Livestock Management, 33 : 39-46.

Zhou, W.T. and Yамамото, S. (1997) Effects of environmental temperature and heat production due to food intake on abdominal temperature, shank skin temperature and respiration rate of broilers. British Poultry Science, 38 : 107-114.

Zhou, W.T., Fujita, M. and Yamamoto, S (1998 a) Effects of food and water withdrawal and high temperature exposure on diurnal variation in blood viscosity of broiler chickens. British Poultry Science, $39:$ 156-160.

Zhou, W.T., Fujita, M., Yamamoto, S., Iwasaki, K., Ikawa, R., Oyama, H. and Horikawa, H. (1998 b) Effects of glucose in drinking water on the changes in whole blood viscosity and plasma osmolality of broiler chickens during high temperature exposure. Poultry Science, $77: 644^{-}$ 647.

Zhou, W.T. and Yamamoto, S. (1998) Heat-induced the shift of body fluid in broiler chickens. Proceedings of the 6th Asian Pacific Poultry Congress, pp. 292-293. Nagoya, Japan.

Zhou, W.T., Fujita, M. and Yamamoto, S. (1999a) Effects of ambient temperatures on blood viscosity and plasma protein concentration of broiler chickens (Gallus domesticus). Journal of Thermal Biology, 24 : 105-112.

Zhou, W.T., Fujita, M. and Yamamoto, S. (1999 b) Thermoregulatory responses and blood viscosity in dehydrated heat-exposed broilers (Gallus domesticus). Journal of Thermal Biology, 24 : 185 192.

Zhou, W.T., Chaiyabutr, N., Fujita, M. and Yamamoto, S. (1999c) Distribution of body fluid and change of blood viscosity in broilers (Gallus domesticus) under high temperature exposure. Journal of Thermal Biology, 24 : 193-197.

Zhou, W.T., Fujita, M. and Yамамото, S. (1999 d) Effects of feed and water intakes on whole blood viscosity and plasma osmolality in broiler chickens. Japanese Poultry Science, 36 : 148-154. 